\title{
Student-Centred Learning in Selected Private Higher Education Institution
}

\author{
Lim Fung Ching, Rasika Lawrence, Haslinda Abdullah
}

\begin{abstract}
The teaching and learning system are currently witnessing a tremendous shift from personal-ised learning to student-centred learning that provide the learners with more autonomous and self-directed learning experience which are very much required by today's digital driven workforce. The aim of this paper is to discuss the advantages and disadvantages of student-centred learning approaches in teaching-learning in Malaysia education industry. Lectures in a selected organisation are chosen for data collection purposes. Data was collected through interviews, observations and focus group discussions which is analysed using content and analytic induction analysis. Data are sorted and categorised into themes to theorize the advantages and disadvantages of student-centred learning in Malaysia Private Higher Learning Education. The findings of this study found that the approach creates a platform or an oppor-tunity to the learners to be more independent mainly in decision making process that encour-ages a learner to be more responsible. Besides, the approach also contributes in a high level of involvement and engagement amongst the students in the learning process that encourages a strong teamwork among students. In addition, the approach also tends to develop both soft and technical skills that lies within the learners which is an important element in today's fast-growing business environment. However, some teachers still prefer the teacher-centred approach which is often criticized to be ineffective in the whole teaching-learning process as it limits a learner's higher cognitive skills. Thus, managing all students at once becomes even more difficult. This study provides insights of the advantages and disadvantages of student-centred learning to the Ministry of Higher Education in Malaysia and to the academics so that strategies in maximising the advantages and strategies in overcoming the disadvantages of student-centred learning can be developed.
\end{abstract}

Keywords: Student Centred Learning, Malaysia Private Higher Education

\section{INTRODUCTION}

Despite its acceptance in the education industry, the student-centred learning approach, is not without its critics. According to O'Neill \& McMahon (2005), there are some difficulties in its implementation whereby the resources needed to implement it and the readiness of the teacher to have a positive mindset to shift from traditional teaching method to personalised teaching style. Therefore, this research is to focus on the Student-Centred Learning in selected Malaysia Higher Learning Institution. The objective of this research is to find out what students can gain from student centred learning

Lim Fung Ching, Faculty of Business, Victoria University of Undergraduate Programme, Sunway College, Kuala Lumpur Malaysia. (Email: limfc@sunway.edu.my)

Rasika Lawrence, Faculty of Business, Victoria University of Undergraduate Programme, Sunway College, Kuala Lumpur Malaysia. (Email: rasikal@sunway.edu.my)

Haslinda Abdullah, Faculty of Defence Studies and Management, National Defence University of Malaysia, Kuala Lumpur, Malaysia. (Email: drhaslinda@gmail.com)
Revised Manuscript Received on October 23, 2019.

\section{STUDENT CENTRED LEARNING IN MALAYSIA}

Over the years, the Malaysian education system had undergone several transformations. There had been a push by the Ministry of Education in Malaysia to move towards outcome-based education. Many approaches were being introduced and being implemented to enhance the teaching and learning system at higher learning institutions and some research carried out by scholars acknowledged that the student-centred learning is an effective way of learning in this current century (Veerasamy, Maniam \& Khan 2017). Dato Seri Mohamed Khaled Nordin, the former Malaysian Minister of Higher Education once said it is essential and important to focus on having an effective curriculum that would help build a holistic learner (Yusof et al, 2013). Student Centred Learning (SCL) approach is currently suggested and highly encouraged in the Malaysian Higher Education classrooms for teaching and learning purposes.

The Ministry of Education (MOE) has put much emphasize for most of the private institutions in Malaysia to implement specific courses such as community service and co-curriculum through the Malaysian Qualifications Agency (MQA). It is believed that this course can enhance certain skills which is very much needed in today's competitive business world, such as the communication skills, critical thinking skills in problem solving through scientific means, apply self-leadership and teamwork skills and utilize information management skills that strengthen and support lifelong learning. Besides, other courses such as presentation skills, ethnic relations, communicative language and entrepreneurship make up the soft skills-oriented subjects as part of all diploma and degree programmes. These efforts are an initiative to cultivate student centred learning to foster a positive learning shift and improving student's performance mainly (Froyd \& Simpson, 2008).

\section{What is Student Centred Learning}

Student centred learning is an approach designed in focusing on the needs, abilities and interest of the students in relation to support the rapidly changing educational environment. According to Larasati (2018), in this approach, a teacher plays an important role as a facilitator instead of being an instructor in learning. Educators are highly encouraged to foster a dynamic, realistic and practical approach in the learning process. According to Lak, Soleimani \& Parvaneh (2017), this classroom approach recognizes the student's involvement at a greater level compared to the traditional approach where teachers are 


\section{Student-Centred Learning in Selected Private Higher Education Institution}

typically controlling the classroom and students are only being a passive learner. According to Zohrabi (2012), student-centred learning approach plays a role in becoming an innovator of development of the learning process. In this approach, the key indicator of the student's activities and the quality and the content of the activities are important in the learning process. There's already a bigger demand for student-centred learning, urged by four digitally driven educational disruptions: analytics, open technologies, 24/7 access to course materials and preparatory education. These four trends are forcing academic institutions to re-evaluate the services they offer, with a focus on enhancing the student experience.

The Advantages of Student Centred from Previous Research

According to Oinam (2017), the student-centred learning approach provides an opportunity to create an independent learner. Tsui (2002) commented that learners are given a platform to choose their courses within their study programme. It is said that some advocates of student-centred learning emphasize that this approach gives them an idea of how to think rather than teaching them what to think. A research done by Kaput (2018) also indicated that students are most likely to be more engaging in their learning when choices are given. They tend to portray more on task behaviour, thus learning environment becomes more cooperative.

The student-centred learning (SLC) approach promotes a beneficial learning environment for any learners. A research done by Hayirserver (2014) found that students gain better knowledge more easily when they learn with student centred learning approaches. As indicated in one of the researches by Taylor \& Parson (2011), today's learners prefer a more impactful learning environment that provides a sense of accomplishment while they can be adaptive and interactive with fellow learners as well as instructors. To foster a more positive learning environment, learning must be interesting and motivating its learners. It must address learner's concerns. An educator should never discourage students from asking questions that can stop a student's desire for continuous learning.

According to Hayırsever (2016), student centred learning approach promotes the participation of a learner at a greater level. The approach puts an important emphasize that the teacher is not the only source of learning in the classroom, students plays an important role in becoming another source in the learning process that contributes to knowledge sharing and active participation Faridi, Bahri \& Nurmasitah,( 2016). One of the recent reports by the New Straits Times (2019) emphasized that it is essential and important to provide every learner with a platform and opportunity to join and contribute to the learning process. Learning is a cooperative activity that requires a higher level of participation. Thus, learning needs to include discussions that promote how to think and express ourselves clearly.

In today's competitive business environment, competency skills are given much importance for any jobs. Employers focus on specific competencies such as knowledge, skills and abilities that can suit and meet the demand. According to Young and Chapman (2010), the term generic competency' is used to refer to competencies that can be applied across different job and life contexts. Males (2010) define generic competency as attributes or skills that are important to graduate across all disciplines. However, it is never easy to explain the SLC concept as some researchers use related terms such as 'generic attributes', 'generic skills' and 'employment skills' to define the generic competencies term Billing (2003). Muianga et al, (2018) added that the student-centred learning approach does not only absorb on the personal and cognitive growth, but also focuses on the development of competencies needed to perform as a professional in a future job or self-employment.

According to Bell \& Baker (2017), the student-centred learning approach encourages a learner to take responsibility for obtaining and conveying new knowledge, as the approach puts a requirement to each learner to perform both lecturer and a student role. A research conducted by Gutstein (2007, p. 424) stated that teachers are often being the enforces, disciplinaries and police officers in the classroom whereby the dominance level is much higher. Basu \& Barton (2010) stated that it is necessary for every educator learn how to segment authority with their students that can empower them to make instructional decisions that the teacher can support and approve. Thus, the teacher is seen as an important factor in becoming a facilitator instead of an instructor who is just being a presenter of information Pitrik \& Holzinger (2002). Muianga et al, (2018) added the role of a lecturer in becoming a facilitator is vital in producing a learner to become a creator instead of just being a listener.

Disadvantages of Student-Centred Learning Approach from Previous Research

Classroom management is an important component of the classroom learning environment. In the student-centred learning approach, students tend to share their opinions and thoughts throughout the discussion's session. During these interactions, they tend to talk and discuss, thus classrooms are often busy, noisy and chaotic. This can be difficult for the teachers to control and manage all the student's activity at once. As we are all aware, some learners prefer to be an individualist compared to be a collectivist. This can again be a challenge for the educators as it is beyond their control Concordia University (2016). Simon (1999) strongly argues that focusing on every single individual in the classroom can be difficult for any teachers. Time plays an important as some teachers focus on slow learners that need more time in the absorbing information compared to a fast learner. This may result in ignoring the fast learner and lead to poor classroom management. Another study conducted by the Australian researchers Roache and Lewis (2011) also stated that not all teachers can be aware of how much they can influence a person's behaviour a teacher only aimed in completion of task during lessons and they tend to use aggression to stop unsuitable behaviour that prevents concentration, which can lead to poor classroom management.

Published By: 
One of the challenges faces by an educator in implementing the student-centred learning approach is that resistance to change from traditional teaching methods Qhobela (2012). In one of the studies conducted by Aksit, Nievmi \& Nevgi (2016), students strongly criticise that some educators still practice and continue the traditional approach in their lecturing. The outcome of the research indicated that the teachers do not follow the transformation introduced in the teaching instead they practice what they have been familiar to do and focus only on student's academic success rather than practical application. This reflects the teacher has the fear of losing their control over the class. Adding on, another research by Peterson (2009) also indicated the same that some group of teachers still prefers the traditional method in teaching to complete their syllabus in the given period of time. In such a situation, Qutoshi \& Poudel (2014) concluded that providing quality education can be challenging and students become more passive and not rational and socially conscious citizens.

\section{METHODOLOGY}

This study uses the basic qualitative research design. According to Abdullah (2019), basic qualitative design can be defined as a type of research that individuals construct reality in interaction with their social worlds. The use of this design is to understand the meaning a phenomenon has for those involved.

Basic quantitative research and data are collected from lecturers in a selected private higher education through interview and discussions. The data is analysed and data obtained through interview using phenomenological analysis which is mainly used to analyse experience according to Abdullah (2019) the aim of this analysis is to arrive at structural descriptions of an experience, the underlying and precipitating factors that account for what is being experienced.

Lecturers in a private higher institution are chosen as a population of this study. The total population of lecturers in this private higher institution is about five hundred, however convenience sampling is chosen to selected lecturers to be interviewed. A total of 10 lectures were selected as sample for this study. These lecturers were interviewed approximately thirty to forty-five minutes with the aid of audiotape as well as manual note taking. After the completion of the interview process, a summary of the interview data is interpreted to the respondents. This is done mainly to obtain the respondents' confirmation and the validity of the information. Each respondent will be briefed and explained the objectives of the interview before the commencement of the interview. Respondents are also notified on the consent form to indicate their readiness to contribute towards this research and to pledge the honesty and the sincerity in providing information and responses. The respondents are guaranteed the confidentiality of responses. Toward this research, ethical conduct is obeyed.

The data collected are analysed using content analytical induction. Analytic induction (AI) can be defined as a process of gathering data, developing analysis and organising findings Katz (2011). There are 2 data collection method that is used in this research, they are the primary source data and secondary source data. A primary data source is an information that the researchers obtain it by themselves. A secondary source data is obtained from the reliable source's information. All information from books, websites, articles and journals were obtained to further this research by the author. Those data that have been collected have already been gathered by the previous researchers.

\section{FINDINGS AND DISCUSSION}

\section{Promotes Independent and Responsible Learner}

One of the advantages of student-centred learning is that it enables a student to be independent and responsible for their own. This leads them to be a more responsible learner especially when a task or activity is been assigned to them directly. As a result, the outcome will depend on the student's effort and planning in which the student had to put in an effort to complete the task. Thus, when the student becomes more independent and responsible in their own learning, that shifts a teacher's new role as a facilitator who will guide the student through their learning process.

This finding revealed that the student-centred learning approach enables a learner to become more independent and responsible which is line with the studies conducted by Oinam (2017). The students would have greater flexibility in choosing their mode of participation. From the lecturer's perspective, a learner automatically becomes more responsible when a specific task is being assigned to them individually. According to a research done by The World Universities ranking, adding both campuses based and distance learning on a module by module basis is a great example of this.

A research conducted by Aksit, Niemi \& Nevgi (2016) revealed that the practical education lessons constructed as student-centred activities, such as drama, laboratory, fieldwork, preparing a portfolio, conducting research, having peer discussions, giving feedback to peers and evaluating themselves add the feeling of ownership to students that create a more independent and responsible learner. Students appreciated the aptitude to apply theory to practical teaching and learning, which necessitates the students to involve and participate in the learning process and take accountability for their own learning instead of inactively listening to the teacher in the classroom.

\section{Collaborative Learning}

In a way, student-centred learning approach also encourages teamwork with high level of involvement throughout the activity. The approach encourages collaborative learning to improve student's participation level in the learning process. It allows the students to learn in a fun and creative way rather than just follow the instruction from the lecturers. Retention of knowledge increase as students learned better when the students participate and engage in the activities. From the lecturer's perspective, collaborative learning can help a learner to develop their thinking skills and improve their confidence 


\section{Student-Centred Learning in Selected Private Higher Education Institution}

and self-esteem level.

Indeed, this study found that the student- centred learning approach encourages teamwork and collaborative learning at a greater level with the involvement of a learner. Collaborative learning is encouraged to mainly improvise the participation level in the learning process. A research by Trinidad \& Ngo (2019) added that by adding the collaborative element in classroom can enhance a learner's engagement and participation at a greater level.

This finding is consistent and similar and has been confirmed by Hayirsever (2016). The author mentioned that the approach focuses and put much emphasis on students rather than the teacher as teacher is not the only source of information to be relied on. Faridi, Bahri \& Nurmasitah (2016) added by saying that students to play an important role in becoming another source of learning in classroom. However, Gillies (2016) argues that putting a bunch of students in a group and expecting them to work together will not certainly promote cooperation. To overcome this, Johnson \& Johnson (2009) suggested groups need to look at the main five key components of successful cooperative learning in the group structure, ie; "Structuring positive interdependence, promotive interaction or the willingness of group members to encourage and facilitate each other's efforts, individual accountability in ensuring that he or she completes his or her share of the work, interpersonal skills required to manage disagreements among group members and group processing involves students reflecting on their progress and their workingRelationships" Trinidad \& Ngo (2019).

\section{Develop Soft and Technical Skills.}

Student-centred learning approach creates an opportunity for learners in developing soft and technical skills. The students will develop soft skills such as communication skills, presentation skills, leadership skills, problem solving and interpersonal skills. These skills are the tangible skills which in the long run will increase the employability of the student once the student graduated. Implementing the student-centred learning approach will also benefit a learner to develop technical skills such as project management skills especially when they are working in a field project as a team. Unlike the traditional learning approach which mainly focuses on memorization methods, that could limit the practical approach in a student's learning journey.

The findings apparently collaborate with the earlier study which shows similarity that implementation of studentcentred learning approach can enhance and develop a learner's competency skills such as critical thinking, research and problem-solving skills. According to Lochhead \& Clement (1980), a teacher should be educating a learner how to think rather than coaching them what to think which is in line with a study conducted by Tsui (2002).

The Malaysian government has emphasised and encouraged highly to implement soft skills in higher education institutions. The government has recognised human capital development as one of the most critical elements in achieving its vision 2020 that incorporates knowledge, skills and attitude, accompanied by soft skill capabilities. Accordingly, the Ministry of Higher Education, Malaysia has clearly recognized and acknowledged the seven important elements of soft skills (Majid et al, 2008) that included communicationse skills, problem solving and thinking skills, continuous learning skill and information management skills, work in group skills, leadership skills, professional ethics and entrepreneurship skills Zabit (2010). However, the term soft skills can be often overlooked as it can varies in meaning for some. A research conducted by Wats \& Watz (2009), mentioned that those skills are needed to perform better, meanwhile for others this can also mean entrance key for better employment.

\section{Shift in The Role of a Lecturer}

In student centred learning approach, a teacher plays a role of a facilitator instead of just being an instructor. Most teachers nowadays teach students how to think themselves instead of spoon feeding them. Most courses are designed in a way that students are required to think and solve problems by themselves. A teacher is only providing a guide to them without interfering. This way the teacher is fostering a comprehensive teaching and learning environment that leads to active participation especially in teamwork. A student should also play an important role in teaching and learning process instead of purely depending on the teacher for transfer of knowledge thoroughly.

This study also found out there is a shift in a role for the lecturer's towards adapting to a facilitator role which is also consistent and similar from a research done by Bell \& Baker (2017). A study by Brophy (1999; p.19) stated that in the student-centred learning approach, a teacher does not convey the knowledge directly to the students, instead students play an active role in the learning process through discussions. Thus, a teacher's role from being a teacher shifts to be a facilitator. As stated by Yukhymenko et.al (2014) a teacher is not an information provider nor a classroom controller. Thus, the entire classroom environment needs a change Jagtap (2015). Tamim \& Grant (2013) identified four (4) main roles a teacher should possess in a classroom namely, reinforcer, extender, initiator and navigator. Findings of Walsh and Vandiver (2007) study indicated that students performed better academically because they had a say in what they learned, and the teachers only acted as facilitators in order to allow the students to learn actively. However, Kazempour (2009) argues that in order for an educator to take up the role of being a facilitator can be challenging if they are not willing to shift their focus in the classroom from lecturing to assessing.

\section{DISADVANTAGES OF STUDENT-CENTRED LEARNING\& RESULTS}

\section{Traditional Method Vs Student Centred Learning}

One of the disadvantages of Student-Centred Learning is that some educators still prefer the traditional way of teaching which is teacher centred learning. This will limit the student thinking process as the teacher take charge of the classroom by giving the students instructions to carried out 
their course work. This will lead to the spoon-feeding method among the students as some students will tend to depend or rely on the answer given by the teacher rather than using their own thinking process.

The found there are still several educators still prefers delivering/conducting the lesson in a more traditional method compared to shifting their teaching style in personalised learning which is in line with the studies conducted by Qhobela (2012) mentioned in the literature review. According to a research done by Liu, Qiao and Liu (2006), the authors indicated that the traditional teaching method is still being dominant in actual practice especially at the university settings. A study conducted by Shor (1996) stated that when the traditional method is in practice, students are not given any opportunity to express what they want, instead they are to accept the way the educators deliver the lesson using their knowledge and experience. Two main possible problems that could occur when a learner perceive their lecturers has the most power in educating the learners, i.e. students have zero contributions to a misunderstanding that learning essentially is the transfer of knowledge from teachers to students, rather than a process that allows making meaning from knowledge. Students' is also perceived powerlessness in their own education translates into a lack of their taking responsibility for their own education according to Abdelmalak \& Trespalacios (2013).

However, Cabe (2014) argues that the transition from a passive learner to active learner is always never been an easy process for both the teacher and students as the implementation could be a stumbling block for some students mainly. Muianga et al, (2018) stated that some learners find it difficult in familiarise themselves to the new role of being an active learner. Sawyer (2016) mentioned that the traditional method of teaching is not in line and not well suited to our knowledge and societies. Therefore, learning scientists are calling for a change in today's education system. However, (O’Neill \& McMahon, 2005; Thanh, 2010) stated that it is difficult for both teachers and learners to assume new roles as they must unlearn previous approaches.

\section{Poor Classroom Management}

Student management and classroom control become more difficult whilst incorporating the student-centred learning approach in classroom. The teacher must be trained and have the necessary experience in conducting the teaching as these could lead to losing control over the students if not handled properly. Some teachers need further understanding of what creates the successful practice of student-centred learning and the best outcomes for learners.

It is found out that implying the student-centred learning approach can become difficult especially when the teachers are inexperienced in managing the students in a bigger classroom. Students can easily get distracted and Shaaban (2018) concluded that this could lead to boredom. The author further stated that it is impossible for all students to pay attention throughout a class and argues the studentcentred learning approach can be boring if it is not being carried out in an interesting manner which is in line with the literature review by Concordia University (2016). Serin
(2018) also stated that sometimes classroom control can become difficult due to behaviour problems too. Mart (2013) argues that however a passionate educator will know how to motivate and encourage students for active learning and concern themselves with promoting students intellectual and moral development. Cabe (2014) also reported another reason for the poor classroom management is due to no formal training provided to lecturers although they are familiar with its academic principles.

\section{CONCLUSION}

A positive change in the education system is essential in preparing future graduates. To maximise learning, every student needs to have a sense of identity and a comfortable learning environment. The study found that there are more advantages in adopting the student-centred learning approach compared to its disadvantages.

This study contributes to the literature by filling up the gap of the literature review and the body of knowledge regarding student centred-learning approach in teaching and learning context. To the policy maker (policy review \& development), this study should be able to deliver understanding regarding the advantages and disadvantages of student-centred learning approach to the ministry of higher education in orderto review policy and strategic direction on the use of student-centred learning approach in classroom. The study should also be able to assist private higher education universities in the use of students centred learning approach more effectively and efficiently. Student centred learning approach is essential in shaping the future education. Educators need to be trained and willing to adopt and implement the approach in teaching and learning.

This research only covers the advantages and disadvantages of the student centre learning in Malaysia higher private education institutions. This might limit the understanding of readers if different institutions are being looked at. Besides, this research is emphasizing more on the viewpoints of the educators from the private higher institution industry, which is mainly the lecturer who is involved in teaching. For the population and sampling method, a larger number of respondents can be included for different categories of respondents such as students and top management. The research is limited to a qualitative analysis which is to be explored into a quantitative analysis for more in depth research. An additional limitation on this research is concerning the trustworthiness, reliability and consistency of feedbacks attained during the interview session. It is a doubt that the respondents would not answer the question sincerely as they might be reserved in giving a sincere answer. This might affect the accuracy and reliability of the results obtained.

Student centred learning approach needed more practice not only in delivering courses to students but also focusing on the training program for the lecturers in order to gain the skills, knowledge and effective application of the approach in the classroom. More research is needed relating to the 


\section{Student-Centred Learning in Selected Private Higher Education Institution}

practical strategy of a student-centred learning approach in different context to find out the limitation related using this approach.

\section{REFERENCES}

1. Abdullah, H (2019). Research Methods and Report Writing UPNM Press

2. Abdelmalak, M., and Trespalacios., J. (2013). Using A LearnerCentred Approach to Develop An Educational Technology Course.

3. Ahmed., AK. (2013). Teacher-Centred Versus Learner-Centred Teaching Style.

4. Aksit, F., Niemi., and Nevgi, A. (2016). Why Is Active Learning So Difficult to Implement?The Turkish Case

5. Attard, A., Loio, ED., Geven, K., and Santa, R. (2010). Studen Centred Learning An Insight Into Theory And Practice Retrieved from http://www.ehea.info

6. Attard, A., Loio, ED., Geven, K., and Santa, R. (2010). Student Centred Learning an Insight Into Theory And Practice.

7. Basu, S. J., \& Barton, A. C. (2010). A Researcher-Student-Teacher Model for Democratic Science Pedagogy: Connections to Community, Shared Authority, And Critical Science Agency.

8. Bell, L., and Baker, SL. (2019). Student-Centred Learning: A SmallScale Study of A Peer-Learning Experience In Undergraduate Translation Classes.

9. Billing, D. (2003). Generic Cognitive Abilities in Higher Education: An International Analysis Of Skills Sought By Stakeholders.

10. Emaliana., I. (2017). Teacher-Centred or Student-Centred Learning Approach to Promote Learning.

11. Faridi, A., Bahri, S., and Nurmasitah, S. (2016). The Problems of Applying Student Centred Syllabus Of English In Vocational High Schools In Kendal Regency.

12. Froyd, J., and Simpson, N. (2008). Student-Centred Learning Addressing Faculty Questions About Student Centred Learning.

13. Gibbs, G. (1995). Assessing Student Centred Courses. Oxford: Oxford Centre for Staff Learning and Development.

14. Gillies., MR. (2016). Cooperative Learning: Review of Research view of Research and Prac-tice and Practice.

15. Gutstein, E. (2007). "An That's Just How It Starts": Teaching Mathematics and Developing Student Agency.

16. Hayirsever., F.and Jacob, DB. (2016). Student-centred Learning: How Does It Work in Prac-tice.

17. Jagtap,. P. (2015). Teachers Role As Facilitator In Learning.

18. Katz, J. (2001). Analytic Induction.

19. Kaput., K. (2018). Evidence for Student-Centred Learning. Retrieved from https://files.eric.ed.gov/fulltext/ED581111.pdf

20. Kazempour, M. (2009). Impact of Inquiry-Based Professional Development on Core Concep-tions And Teaching Practices.

21. Keiler., LS. (2018). Teachers' Roles and Identities In Student-Centred Classrooms. Interna-tional Journal of STEM Education.

22. Lak, M., Soleimani, H., and Parvaneh, F. (2017). The Effect of Teacher-Centeredness Method Vs. Learner-Centeredness Method on Reading Comprehension Among Iranian EFL Learners.

23. Larasati, F., (2018). Student Centred Learning: An Approach to Develop Speaking Skill in EFL Classroom.

24. Liu,. R, Qiao,. X, Liu., Y. (2006). A Paradigm Shift of LearnerCentred Teaching Style: Reality or Illusion?

25. Mart, C.T. (2013). A Passionate Teacher: Teacher Commitment and Dedication to Student Learning.

26. Moustafa, A., Assaraf, OBZ., and Eshach, H. (2012). Do junior high school students perceive their learning environment as constructivist?

27. Muianga, X., Klomsri, T., Tedre, M., and Mutimucuio, I. (2018) From Teacher-Oriented to Student-Centred Learning: Developing An ICT-Supported Learning Approach at The Eduardo Mondlane University, Mozambique.

28. Oinam., S. (2017). Student- Centred Approach to Teaching and Learning in HigherEducation for Quality Enhancement.

29. O'Neill., G. and McMahon, T., (2005). Student-Centred Learning: What Does It Mean for Students and Lecturers.

30. Postholm, MB., (2013). Classroom Management: What does research tell us?

31. Qhobela, M. (2012). Using Argumentation as A Strategy of Promoting Talking Science in A Physics Classroom: What Are Some of The Challenges?

32. Qutoshi, SB., and Poudel, T. (2014). Student centred approach to teaching: What does it mean for the stakeholders of a community school in Karachi, Pakistan?

33. Serin, H,. (2018). A Comparison of Teacher-Centred and StudentCentred Approaches in Educational Settings.
34. Shaaban, S,.(2018). Reporting the Impact of Student-Centred Learning (SCL): Interactive Learning Experience Based on SmallScale Study In Undergraduate Business Classes.

35. Shor, I. (1996). When Students Have Power: Negotiating Authority in A Critical Pedagogy. Chicago, IL: University of Chicago Press. Sutphin, C. (1992).

36. Simon, B. (1999). Why No Pedagogy in England? In J. Leach and B. Moon (Eds.), Learners And Pedagogy. London: Sage Publications.

37. Trinidad., JS. (2019). Technology's Roles in Student-Centred Learning in Higher Education.

38. Tsui., L. (2002). Fostering Critical Thinking through Effective Pedagogy.

39. Veerasamy, C,. Maniam, V. and Khan., B. (2017). Student Centred Learning (SCL): New Learning Approach in Malaysian Tertiary Education System

40. Walsh, J. and Vandiver, D. (2007). Fostering Student Centred Learning (SCL) Through the Use of Active Learning Exercises in Undergraduate Research Methods Courses.

41. Wats,.M. and Wats,. RK. (2009). Developing Soft Skills in Students.

42. Young., J and Chapman,. E. (2010). Generic Competency Frameworks: A Brief History Overview.

43. Yukhymenko, M. A., Brown, S. W., Lawless, K. A., Brodowinska, K., \& Mullin, G. (2014). Thematic Analysis of Teacher Instructional Practices And Student Responses In Middle School Classrooms With Problem-Based Learning Environment

44. Yusoff, N, M., Karim, A,M,K., and Othman, R, Rahman,S,A,A,.(2013). Student-Centred Learning (SCL) In the Malaysian Higher Education Institutions.

45. Zabit., MNM. (2010). Problem-Based Learning on Students"e Critical Thinking Skills In Teaching Business Education In Malaysia.

46. Zohrabi., M. Torabi., MA. and Baybourdiani., P. (2012). TeacherCentred and/or Student-Centred Learning: English Language in Iran. 